\title{
Identification of three-way DNA junction ligands through screening of chemical libraries and validation by complementary in vitro assays
}

\author{
Katerina Duskova, ${ }^{1}$ Jérémy Lamarche, ${ }^{1}$ Souheila Amor, ${ }^{2}$ Coralie Caron,,${ }^{3,4}$ Nicolas Queyriaux, ${ }^{5}$ \\ Marie Gaschard, ${ }^{6}$ Marie-José Penouilh, ${ }^{7}$ Guillaume de Robillard, ${ }^{1}$ Dominique Delmas, ${ }^{2}$ Charles H. \\ Devillers, ${ }^{1}$ Anton Granzhan, ${ }^{3,4}$ Marie-Paule Teulade-Fichou, ${ }^{3,4}$ Murielle Chavarot-Kerlidou, ${ }^{5}$ \\ Bruno Therrien, ${ }^{7}$ Sébastien Britton ${ }^{8} \&$ David Monchaud ${ }^{1, \star}$
}

\footnotetext{
${ }^{1}$ Institut de Chimie Moléculaire (ICMUB), CNRS UMR6302, UBFC, 21078 Dijon, France. ${ }^{2}$ Lipids, Nutrition \& Cancers (LNC), INSERM U1321, UBFC, 21000 Dijon, France. ${ }^{3}$ Institut Curie, PSL Research University, CNRS UMR9187, INSERM U1196, 91405 Orsay, France. ${ }^{4}$ Université Paris-Sud, Université Paris Saclay, 91405 Orsay, France. ${ }^{5}$ Laboratoire de Chimie et Biologie des Métaux, Université Grenoble Alpes, CNRS UMR5249, CEA, 38054 Grenoble, France. ${ }^{6}$ Institut de Chimie, Université de Neuchâtel, CH-2000 Neuchatel, Switzerland. ${ }^{7}$ Pôle Chimie Moléculaire (PACSMUB), Faculté des Sciences Mirande, UBFC, 21078 Dijon, France. ${ }^{8}$ Institut de Pharmacologie et de Biologie Structurale, IPBS, CNRS UMR5089, Université de Toulouse, UPS, 31077 Toulouse, France ; équipe labellisée la Ligue Contre le Cancer.
}

Abstract. The human genome is replete with repetitive DNA sequences that can fold into thermodynamically stable secondary structures such as hairpins and quadruplexes. Cellular enzymes exist to cope with these structures whose stable accumulation would result in DNA damage through interference with DNA transactions such as transcription and replication. Therefore, chemical stabilization of secondary DNA structures offers an attractive way to foster DNA transaction-associated damages to trigger cell death in proliferating cancer cells. While much emphasis has been recently given to DNA quadruplexes, we focused here on three-way DNA junctions (TWJ) and report on a strategy to identify TWJ-targeting agents through a combination of in vitro techniques (TWJ-Screen, PAGE, FRET-melting, ESI-MS, dialysis equilibrium and SRB assays). We designed a complete workflow and screened 1200 compounds to identify promising TWJ-ligands selected on stringent criteria in terms of TWJ folding ability, affinity and selectivity. 


\section{Introduction.}

DNA transactions (replication and transcription) are finely orchestrated cellular processes that are frequently challenged by situations of crisis notably when dealing with damaged DNA, secondary structures or in situations of nucleotide pools shortage or imbalance, which can result in DNA and RNA polymerase stalling. ${ }^{1,2}$ If persistent, these polymerase arrests activate the DNA damage response that includes DNA repair mechanisms and that dictates cell tolerance and survival. ${ }^{3,4}$ Crisis-inducers can lead to genomic instability and eventually to cell death if DNA repair is unsuccessful, unfaithful or generates toxic products. Sources of such situations can be endogenous (e.g., stochastic nucleotide misincorporation, reactive oxygen species (ROS)-promoted lesions) or exogenous (e.g., irradiation, genotoxic compounds)..$^{5,6}$

Several anticancer therapies rely on genotoxic chemicals that triggers covalent DNA damages including cross-links (e.g., cisplatin), alkylated bases (e.g., temozolomide), or trapped topoisomerase I and II complexes (e.g., camptothecin analogues and etoposide) ${ }^{7,8}$ An alternative approach would be to consider chemicals capable of stabilizing DNA secondary structures that might arise during DNA transactions. ${ }^{9,}{ }^{10}$ Repeated DNA sequences are indeed prone to fold into higher-order structures in response to the torsional stress provoked by the progression of polymerases. These secondary structures (i.e., hairpin, G-quadruplex, R-loop, DNA junction), whose nature depends on the sequences involved (i.e., direct or inverted tandem repeats), represent topological obstacles the cellular machinery must cope with efficiently to proceed, mostly through the dedicated helicases. ${ }^{11}$ Stabilizing these structures by chemicals thus represent an innovative way to trigger cell crisis and death in cells defective for genome maintenance mechanisms.

Over the past years, most emphasis has been given to G-quadruplexes as roadblocks to DNA transactions $^{12-14}$ but also as new and promising genetic switches to control gene expression. ${ }^{15,16}$ Alternatively, we $\mathrm{e}^{17-19}$ and others ${ }^{20-27}$ have invested efforts to study DNA junctions as druggable targets, chiefly three-way DNA junctions (TWJ). We recently developed the high-throughput screening (HTS) 
assay TWJ-Screen that allows for identification in vitro of promising TWJ-interacting compounds (or TWJ-ligands) in vitro. ${ }^{19}$ To be selective, ligands must interact with the structural peculiarity of the TWJ structure, that is, the branch point: this cavity, at the very heart of the structure, results from the convergence of the three duplex arms that constitute the TWJ (Figure 1A). Here, we kept on searching for new TWJ-ligands evaluating 1200 candidates from 3 different chemical libraries. We then further investigated the TWJ-interacting properties of the best candidates via a series of complementary in vitro assays (PAGE, FRET-melting, ESI-MS and equilibrium dialysis) to gain reliable insights into their affinity and selectivity for TWJ.

\section{Results and Discussion.}

Selection of chemical libraries for TWJ-screen evaluations. To assess whether the TWJ-Screen assay is suited to screen wide collections of small-molecule candidates, we used 3 different chemical libraries: $i$ - The Pathogen Box ${ }^{\oplus}$, from Medicines for Malaria Venture (MMV). ${ }^{28,29}$ This library, available free of charge, comprises 400 drug-like molecules intended to be assayed against neglected tropical diseases including malaria, tuberculosis, toxoplasmosis, dengue, etc. Chemical structures can be found at https://www.pathogenbox.org/about-pathogen-box/composition. ii- The chimiothèque Nationale Essentielle (CNE, version 2017) $;^{30}$ this library comprises 640 compounds, either synthetic or natural products, gathered from different French laboratories under the authority of the French Chemical Library. This library is commercially available; the full list of chemicals cannot be shown due to owner restriction. And iii- the so-called ICMUB library comprising 160 compounds that have been assembled by our group through national and international collaborations over the years. The full list of compounds cannot be shown due to confidentiality issues; however, the chemical structures of all identified hits are shown in Figure 1. Collectively, these 3 libraries represent a total of 1200 candidates, which display a very high level of chemical diversity. 

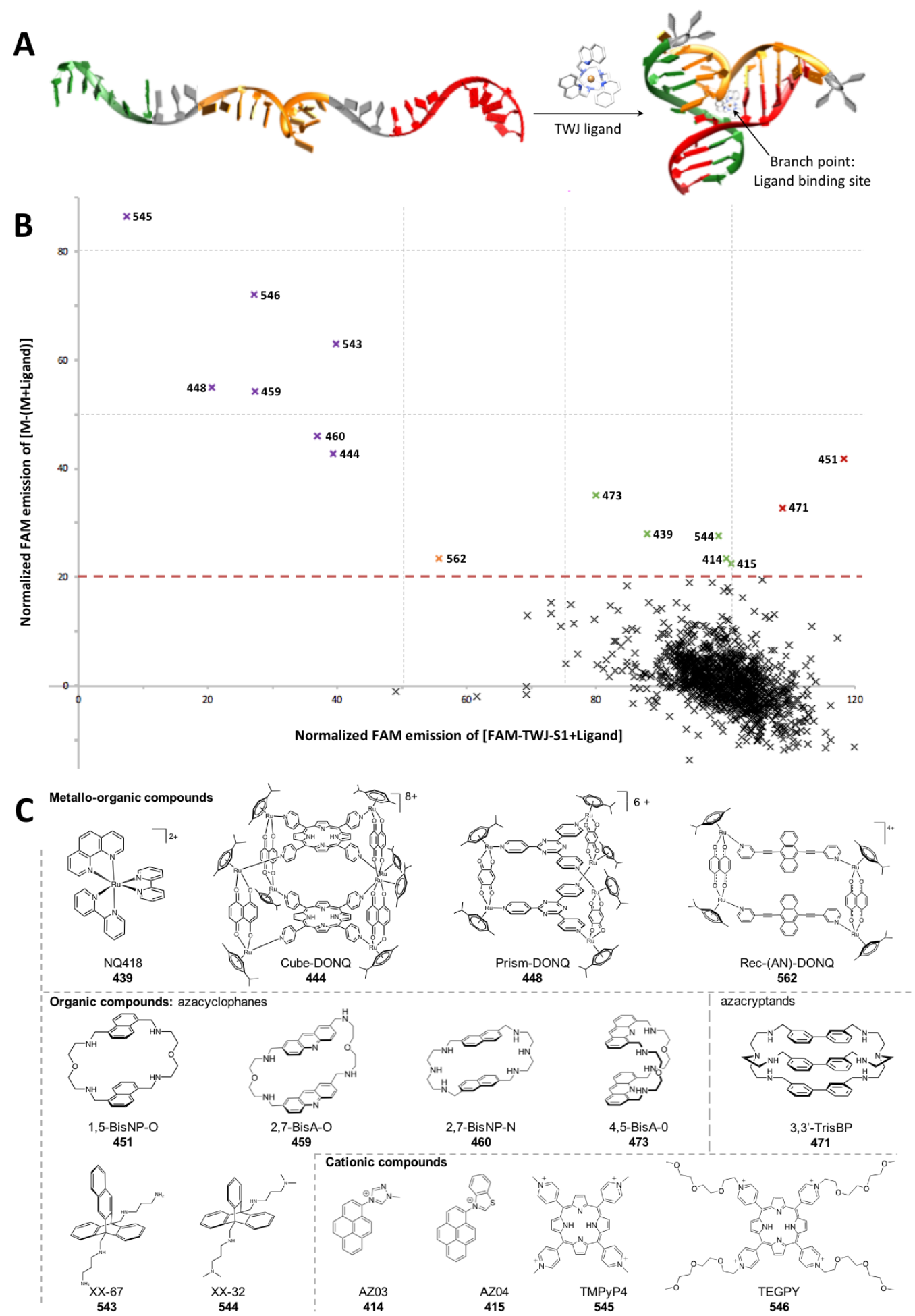

azacryptands
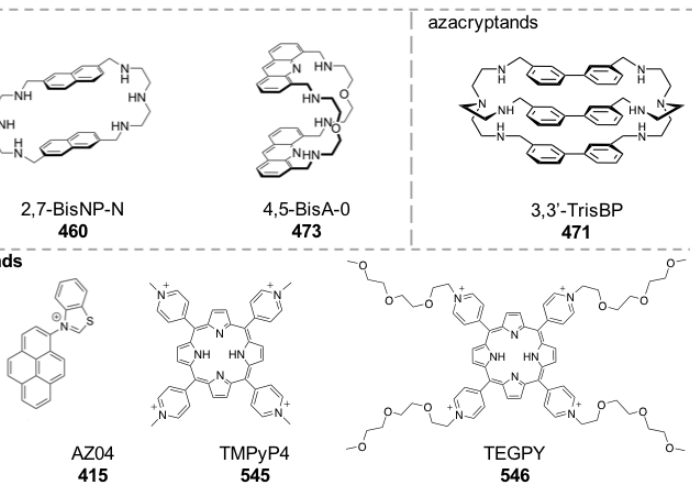

473

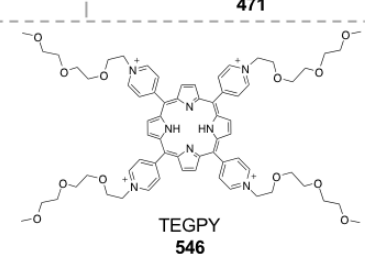

Figure 1. A. Schematic representation of the folding of a TWJ structure. B. TWJ-Screen results of a library of 1200 compounds, expressed as the \% of quenched FAM fluorescence of the three strands mixture (M) in presence of 5 mol. equiv. candidate (i.e., $\mathrm{M}$-( $\mathrm{M}$ +ligand), $\mathrm{Y}$-axis) as a function of the \% of FAM-TWJ-S1 fluorescence measured in presence of 5 mol. equiv. candidate (i.e., FAM-TWJ-S1+ligand, X-axis). Experiments performed with $0.2 \mu \mathrm{M}$ DNA, without or with $1.0 \mu \mathrm{M}$ candidates, in $10 \mathrm{mM}$ lithium cacodylate plus $10 \mathrm{mM} \mathrm{KCl} / 90 \mathrm{mM} \mathrm{LiCl}, \mathrm{pH} 7.2$ at 37 ${ }^{\circ} \mathrm{C}$ for $1 \mathrm{~h}$. C. Chemical structures of the top 15 ligands identified through TWJ-Screen evaluation. 
Table 1. Top TWJ-ligands selection on the basis of TWJ-Screen, PAGE and FRET-melting assays.

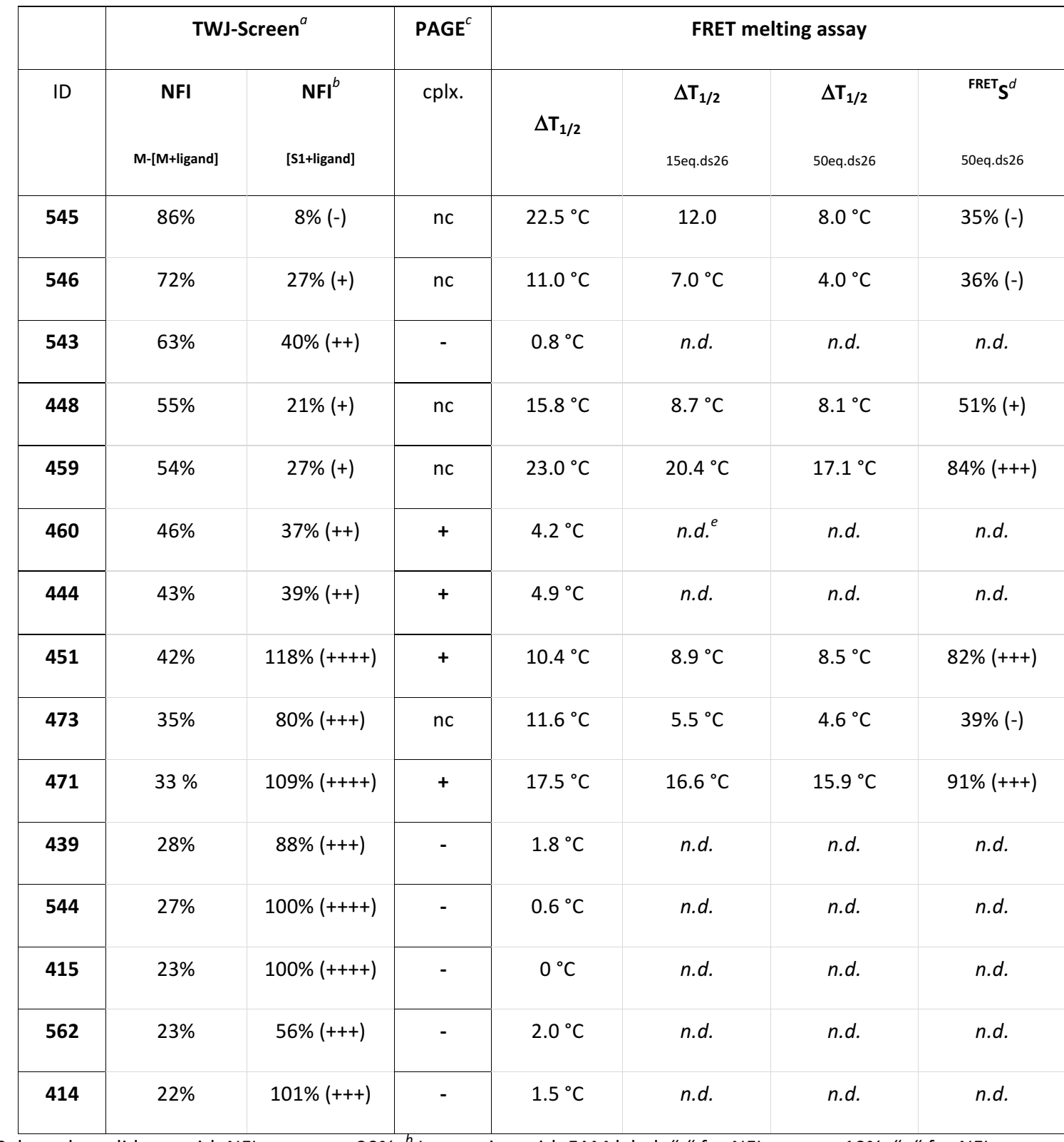

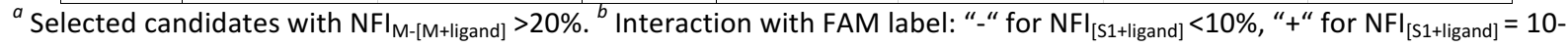

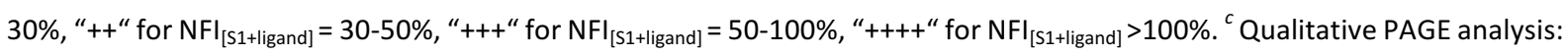
"nc" for non-conclusive, "_" for no detectable TWJ/ligand complex, "+" for detectable TWJ/ligand complex. ${ }^{d}$ Selectivity

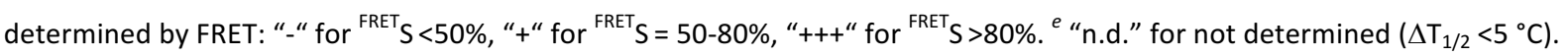

An improved version of the TWJ-Screen assay. The TWJ-Screen assay allows for quantifying the TWJ-folding ability of chemical compounds in HTS manner. ${ }^{19}$ This method is based on the ligandpromoted formation of a TWJ structure from a mixture of the three separated strands, two of them being labeled with fluorophores (one with fluorescein amidite, or FAM, the other one with tetramethylrhodamine, or TAMRA). The ligand-promoted TWJ formation results in the FAM and 
TAMRA fluorophore being in proximity resulting in the quenching of FAM fluorescence that represents a quantitative measurement of TWJ formation. The TWJ-Screen protocol was slightly adapted to screen wider chemical libraries: the initial protocol was performed at room temperature (that is, in a $20-25{ }^{\circ} \mathrm{C}$ range), making the temperature the only parameter left uncontrolled. For improving its reproducibility, the TWJ-screen was here implemented at a fixed temperature of $37^{\circ} \mathrm{C}$. This higher temperature was selected since it allowed for a/ improving the reproducibility of the assay, lessening the unassisted assembly of the three separated strands into a TWJ structure (vide infra), and b/ selecting candidates in a more stringent manner, given that they have to fold and interact with TWJ in less favorable thermal conditions. We screened approximately 60 candidates/day, using the initially described conditions: in $100 \mu \mathrm{L}$ (final volume) of buffered solution (10 mM lithium cacodylate buffer, $\mathrm{pH} 7.2$, supplemented with $10 \mathrm{mM} \mathrm{KCl} / 90 \mathrm{mM} \mathrm{LiCl}$, or Caco.K) were introduced $2 \mu \mathrm{M}$ of the three strands initially introduced by N. B. Leontis et al. ${ }^{31}$ and further studied by V. Brabec et al. for their ability to assemble into a TWJ stable only upon interaction with ad hoc ligands, ${ }^{22}$ that is, FAM-TWJ-S1 (FAM-d $\left[\left[^{5^{\prime}} \mathrm{CG}_{2} \mathrm{~A}_{2} \mathrm{CG}_{2} \mathrm{CACTCG}^{3^{\prime}}\right]\right), \quad$ TWJ-S2 $\left.\quad\left(\mathrm{d}^{5^{\prime} \text { CGAGTGCAGCGTG }}{ }^{{ }^{\prime}}\right]\right)$ and TWJ-S3-TAMRA ( $\left.d{ }^{5^{\prime}} \mathrm{C}_{2} \mathrm{ACGCTCGT}{ }_{2} \mathrm{C}_{2} \mathrm{G}^{3}\right]$-TAMRA). Then, 5 molar equivalents (mol. equiv., i.e., $1.0 \mu \mathrm{M}$ ) of candidate were introduced (except in control wells, vide infra), as triplicates. The microplate preparation is completed with 6 control wells, i.e., 3 wells with FAM-TWJ-S1 alone (to define the $100 \%$ FAM emission) and 3 wells with the 3 separated strands (a mixture termed " $M$ », to verify the lack of spontaneous TWJ folding. The microplate is centrifuged $(30 \mathrm{~s})$, then gently stirred for $1 \mathrm{~h}$ at $37{ }^{\circ} \mathrm{C}$ prior to fluorescence reading. The proficiency of candidates to shift the equilibrium towards the folded TWJ is quantified by comparing the normalized FAM intensity (NFI) of FAM-TWJ-S1 alone (defined as 100\%) with that of [FAM-TWJ-S1+ligand] (for discarding unwarranted compound's interaction with S1) on one hand, and the NFI of the mixture M vs. [M+ligand] (that quantifies the TWJ folding per se) on the other hand. Collected results are shown in Figure 1B and Table 1. The vast majority of the 1200 compounds screened were found ineffective $\left(\mathrm{NFI}_{\mathrm{M}-[\mathrm{M}+\text { ligand] }} \rightarrow 0 \%, \mathrm{NFI}_{\text {[FAM-TW]-S1+ligand] }} \rightarrow 100 \%\right)$ but 15 candidates emerged, displaying $\mathrm{NFI}_{\mathrm{M}-[\mathrm{M}+\text { ligand] }}$ values $>\mathbf{2 0} \%$ (red dashed line, Figure $1 \mathrm{~B}$ ) (the complete 
TWJ-screen results is provided as Supplementary Material). These ligands, i.e., compounds 414, 415, 439, 444, 448, 451, 459, 460, 471, 473, 543, 544, 545, 546 and 562, illustrated all possible scenarios, from candidates that display a good ability to fold TWJ without interacting with the FAM label (flagged as "++++" in Table 1; e.g., 451, with $\mathrm{NFI}_{\mathrm{M}-[\mathrm{M}+\text { ligand] }}=42 \%$ and $\mathrm{NFI}_{[\text {FAM-TWJ-S1+ligand] }}>100 \%$ ) to compounds with very high $\mathrm{NFI}_{\mathrm{M}-[\mathrm{M}+\text { ligand] }}$ and very strong interaction with $\mathrm{FAM}$ label (flagged as "-"in Table 1; e.g., 545, with $\mathrm{NFI}_{\mathrm{M}-[\mathrm{M}+\text { ligand] }}=86 \%$ and $\mathrm{NFI}_{[\mathrm{FAM}-\mathrm{TWJ}-\mathrm{S} 1+\text { ligand] }}=8 \%$ ). The TWJ-Screen assay thus allowed for sorting molecules in a very stringent manner. The chemical structures of the 15 candidates are shown in Figure 1C. It is unsurprising to find previously identified hits, ${ }^{18,19}$ including the azacyclophanes 1,5BisNP-O (451), 2,7-BisA-O (459), 2,7-BisNP-N (460), and 4,5-BisA-O (473) and the azacryptand 3,3'TrisBP (471), ${ }^{32}$ and the metallacages Cube-DONQ (444) and Prism-DONQ (448). ${ }^{33}$ We also identified new candidates (all from ICMUB library) that all display well-defined molecular shapes and volumes: the ruthenium trisdiimine complex NQ418 (439); two new triptycene derivatives XX-67 (543) and XX32 (544), whose synthesis will be described elsewhere (A.Granzhan et al.), structurally close to the compounds previously studied by D. Chenoweth and coworkers; ${ }^{25,}{ }^{26}$ and a newly reported organometallic cage Rec-(AN)-DONQ (562). ${ }^{34}$ Classical DNA intercalators are also identified, notably two porphyrins, TMPyP4 (545) ${ }^{35}$ and TEGPy $(\mathbf{5 4 6}),{ }^{36}$ and two cationic pyrene derivatives, AZO3 (414) and AZO4 (415), ${ }^{37}$ owing to their innate ability to interact with negatively charged nucleic acids.

Confirming the TWJ-folding capability via non-denaturing PAGE analyses. To further investigate the intrinsic quality of the 15 identified candidates, their TWJ-folding capabilities were subsequently investigated by non-denaturing PAGE analysis, according to the methodology described by V. Brabec et al. ${ }^{22}$ We used the same TWJ-forming strands, TWJ-S1, TWJ-S2 and TWJ-S3 (without fluorescent labels). The obtained gels (15\% polyacrylamide, $5 \mu \mathrm{M}$ DNA loading/well), presented in Figure $2 \mathrm{~A}$, offered a straightforward-but qualitative-reading of the TWJ folding ability of the candidates, visualized by the difference of migration between the TWJ-S1 alone and the mixture of strands $\mathrm{M}$ (lower dashed rectangle) and the folded TWJ/ligand complexes, which migrate significantly more 
slowly (upper dashed rectangle). Five compounds were found efficient in these conditions (red arrows), i.e., 444, 448, 451, 460 and 471; four compounds lead to smeared band (green arrows), i.e., 459, 473, 545 and 546, thus making conclusion hard to draw solely on the PAGE basis; and six compounds were found inactive (yellow arrows), i.e., 414, 415, 439, 543, 544 and 562. Given that PAGE conditions are known to be challenging for non-covalent assemblies, these results underline the good TWJ-interacting properties of the 5 most efficient compounds.

A
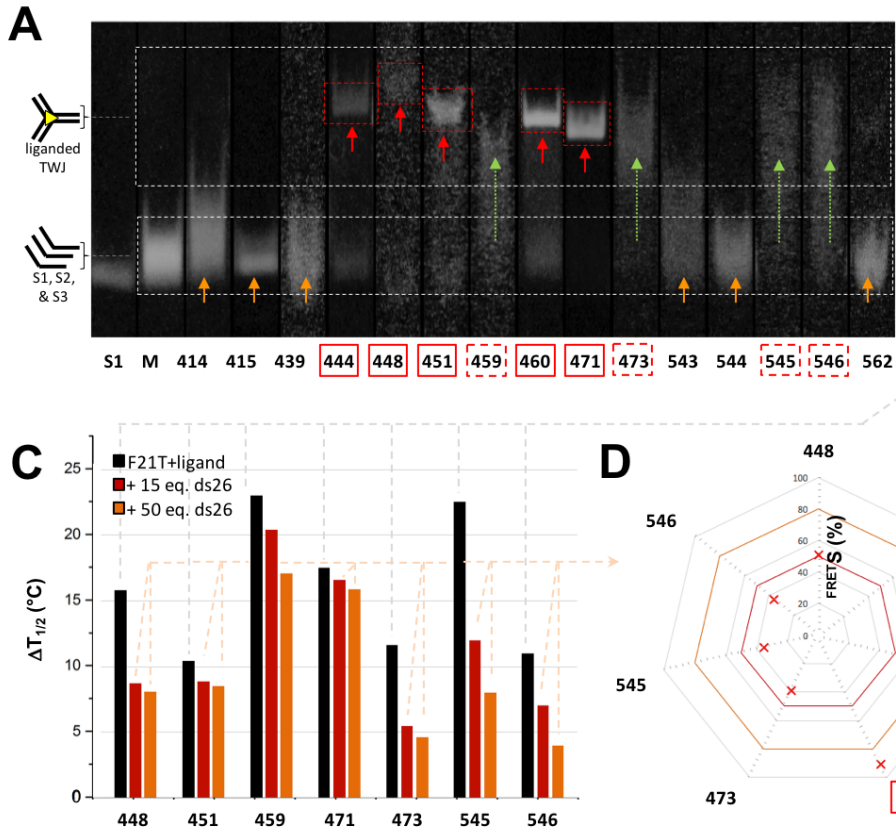
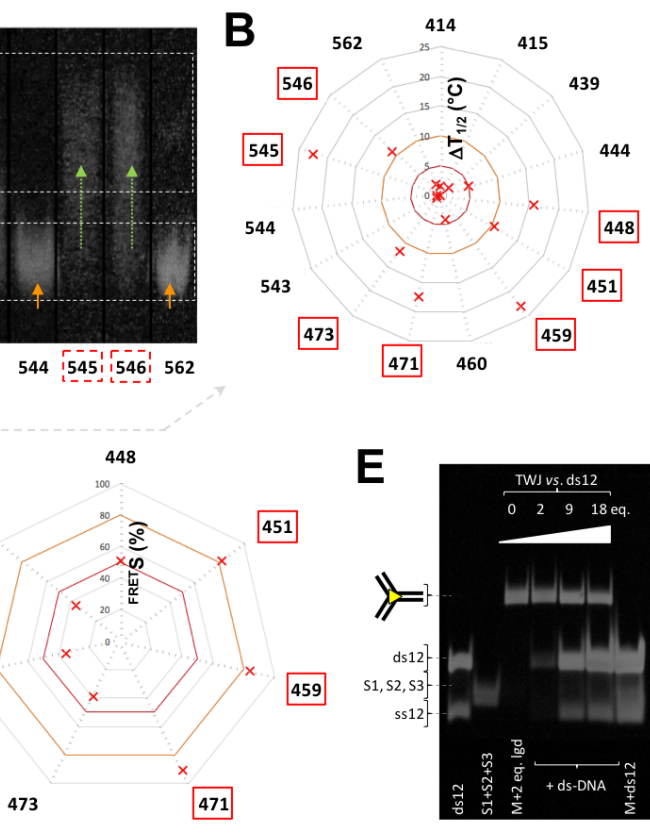

E

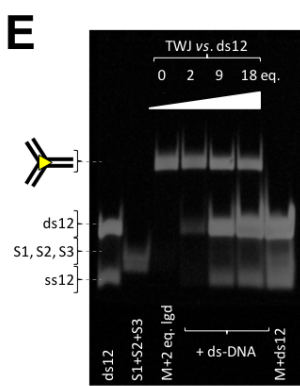

Figure 2. A. PAGE analysis performed with TWJ-S1 $(5.0 \mu \mathrm{M}), \mathrm{M}(5.0 \mu \mathrm{M})$ in absence and presence of the top 15 ligands (5 mol. equiv.) in TBE buffer $+100 \mathrm{mM} \mathrm{NaCl}, \mathrm{pH} \mathrm{8.3,} \mathrm{at} 4{ }^{\circ} \mathrm{C}$ for $1 \mathrm{~h}$ (gels were post-stained with SybrGold $^{\mathrm{TM}}$; multiple gels assembled in a single image) B-D. FRET-melting experiments performed with F-TWJ-T and the top 15 ligands in either a comparative $(\mathbf{B}, \mathbf{C})$ or competitive manner $(\mathbf{C}, \mathbf{D}$, i.e., in presence of increasing amounts of ds26 (up to 50 mol. equiv.)) expressed as $\Delta \mathrm{T}_{1 / 2}$ values (in ${ }^{\circ} \mathrm{C}$ ). Best candidates $\left(\Delta \mathrm{T}_{1 / 2}>10^{\circ} \mathrm{C}, \mathrm{B}\right.$ and ${ }^{\text {FRET }} \mathrm{S}>80 \%$ in presence of 50 mol. equiv. ds26, D) are highlighted in red. Experiments performed with $0.2 \mu \mathrm{M}$ DNA, without or with $1.0 \mu \mathrm{M}$ candidates, with or without 3 and $10 \mu \mathrm{M}$ ds 26 , in $10 \mathrm{mM}$ lithium cacodylate plus $10 \mathrm{mM} \mathrm{KCl} / 90 \mathrm{mM} \mathrm{LiCl}, \mathrm{pH} \mathrm{7.2,} \mathrm{between} 25$ and $90{ }^{\circ} \mathrm{C}$. E. PAGE analysis of competitive experiments performed with TWJ strands, 471 ( 2 mol. equiv.) and increasing amounts of ds12 (up to 18 mol. equiv.) in TBE buffer +100 $\mathrm{mM} \mathrm{NaCl}, \mathrm{pH} 8.3$, at $4{ }^{\circ} \mathrm{C}$ for $45 \mathrm{~min}$ (gels are post-stained with SybrGold ${ }^{\mathrm{TM}}$ for visualizing ds12 and unfolded ds12, i.e., ss12). 
Investigating the TWJ-interacting properties via FRET-melting assay. We also assessed whether the 15 identified ligands interact with a pre-folded TWJ structure. To this end, their ability to stabilize folded DNA junctions against thermal denaturation was evaluated by FRET-melting assay, using the doubly labeled FAM-d $\left[{ }^{5^{\prime}} \mathrm{A}(\mathrm{CT})_{2}(\mathrm{TC})_{2} \mathrm{G}-\mathrm{T}_{6}-\mathrm{C}(\mathrm{GA})_{2} \mathrm{GCGAC}-\mathrm{T}_{6}-\mathrm{GTCGC}(\mathrm{AG})_{2} \mathrm{~T}^{3^{\prime}}\right]$-TAMRA system (FAM-TWJTAMRA, or F-TWJ-T). ${ }^{35}$ Experiments were performed as follows: in $100 \mu \mathrm{L}$ (final volume) of buffered solution (Caco.K), $0.2 \mu \mathrm{M}$ of F-TWJ-T in absence (control wells) or presence of 5 molar equivalents (i.e., $1.0 \mu \mathrm{M}$ ) ligands (as triplicates) were heated from 25 to $75{ }^{\circ} \mathrm{C}\left(1{ }^{\circ} \mathrm{C} / \mathrm{step}\right)$. The melting of the DNA structure was monitored through the FAM emission (quenched at low temperature due to the close proximity with TAMRA in folded TWJ, and restored at elevated temperature due to the thermal unfolding of the DNA junction): the thermal stability of F-TWJ-T, expressed as its melting temperature $\mathrm{T}_{1 / 2}$ (here, $\mathrm{T}_{1 / 2}=43.4{ }^{\circ} \mathrm{C}$ in absence of ligand) increased up to $63.4{ }^{\circ} \mathrm{C}$ in presence of the best TWJstabilizer (compound $459, \Delta \mathrm{T}_{1 / 2}=23.0^{\circ} \mathrm{C}$, Table 1 ). The $\Delta \mathrm{T}_{1 / 2}$ values for the 15 selected compounds are reported in Figure 2B: only 7 of these candidates $(448,451,459,471,473,545$ and 546$)$ imparted a significant stability $\left(\Delta \mathrm{T}_{1 / 2}>10^{\circ} \mathrm{C}\right.$, Table 1$)$. Compounds 444 and 460 , yet the most promising candidates by PAGE, would have been discarded on the FRET-melting result basis $\left(\Delta \mathrm{T}_{1 / 2}=4.9\right.$ and $4.2{ }^{\circ} \mathrm{C}$, respectively); conversely, $\mathbf{4 5 9}$, the most efficient TWJ-stabilizer here, lead to debatable PAGE results: this discrepancy illustrated that TWJ-Screen and FRET-melting assays monitored 2 different processes (TWJ-folding on one hand, stabilization of folded TWJ in the other hand), thus making these two tests complementary.

The TWJ-interacting properties of these 7 candidates were further investigated via competitive FRET-melting experiments, to assess their TWJ selectivity over duplex-DNA. Experiments were performed with F-TWJ-T, 5 mol. equiv. of ligand, in absence (control wells) or presence of 15 or 50 mol. equiv. of a duplex competitor, here ds26 (comprised of two self-complementary strands ss 26 $\left.d\left[{ }^{5} \mathrm{CA}_{2} \mathrm{TCG}_{2} \mathrm{ATCGA}_{2} \mathrm{~T}_{2} \mathrm{CGATC}_{2} \mathrm{GAT}_{2} \mathrm{G}^{3}\right]\right)$. The capacity of a ligand to withstand the excess of $\mathrm{ds} 26$ was expressed as ${ }^{\mathrm{FRET}} \mathrm{S}$ values $\left({ }^{\mathrm{FRET}} \mathrm{S}=\left(\Delta \mathrm{T}_{1 / 2}[+\mathrm{ds} 26] / \Delta \mathrm{T}_{1 / 2}[\right.\right.$ no ds26]) $\times 100$, in \%). Results seen in Figure $2 \mathrm{C}$ and Table 1 indicate that 3 compounds only are both good stabilizers $\left(\Delta \mathrm{T}_{1 / 2}>10^{\circ} \mathrm{C}\right)$ and selective $\left({ }^{\mathrm{FEET}} \mathrm{S}\right.$ 
$>80 \%)$, i.e., the azacyclophanes 451 and 459 and the azacryptand 471, making them the most promising ligands identified through this 3-step selection process. Finally, these results also discarded the two porphyrins (545 and $\mathbf{5 4 6}$ ) as false positives, owing to their low selectivity ( ${ }^{\text {FRET }} S=35$ and $36 \%$, respectively), which makes them prone to interact with nucleic acids whatever their secondary structures.

Of note, the exquisite selectivity of $471\left({ }^{\mathrm{FRET}} \mathrm{S}=91 \%\right.$, Table 1$)$ was further investigated via a competitive PAGE analysis performed with an excess (2, 9 and 18 mol. equiv.) of duplex-DNA (here ds12, comprised of two self-complementary strands ss $\left.\left.12 \mathrm{~d}^{5^{\prime}} \mathrm{CGCGA}_{2} \mathrm{~T}_{2} \mathrm{CGCG}^{3^{\prime}}\right]\right)$. Results seen in Figure $2 \mathrm{E}$ confirmed that the TWJ folding capability of $\mathbf{4 7 1}$ withstands the presence of competitive duplexes, thereby further demonstrating its selectivity for DNA junctions.

Collectively, these results highlight the necessity of performing TWJ-Screen, PAGE and FRET-melting evaluations in a stepwise manner to identify promising ligands on a reliable basis. In the present case, 3 compounds passed this series of tests successfully, namely the macrocycles 451 and 459 (1,5-BisNP$\mathrm{O}$ and 2,7-BisA-O, respectively) and the macrobicycle $\mathbf{4 7 1}$ (3,3'-TrisBP).

Quantifying the ligand/TWJ DNA association by ESI-MS and equilibrium dialysis analyses. We next investigated further the TWJ-interacting properties of 451, 459 and $\mathbf{4 7 1}$ via electrospray ionization mass spectrometry (ESI-MS). This technique provides a unique opportunity to directly access both the equilibrium affinity constants $(\mathrm{K})$ and the stoichiometry of the ligand/DNA association, as already documented with duplex- and quadruplex-DNA, ${ }^{38}$ but not yet applied to DNA junctions. Investigations were here performed with both the pre-folded TWJ used for FRET-melting investigations (without fluorescent labels), and the duplex-DNA ds17 (d $\left.\left.\left[{ }^{5^{\prime}} \mathrm{C}_{2} \mathrm{AGT}_{2} \mathrm{CGTAGTA}_{2} \mathrm{C}_{3}{ }^{3}\right] / \mathrm{d}^{5^{\prime}} \mathrm{G}_{3} \mathrm{~T}_{2} \mathrm{ACTACGA}_{2} \mathrm{CTG}_{2}{ }^{\prime}\right]\right)$. Measurements were performed in 80:20 (v/v) ammonium acetate buffer (100 mM, pH 7.0):MeOH, with $5 \mu \mathrm{M}$ DNA and increasing amounts of ligands (from 0 to 2 mol. equiv.). Results obtained with 471 (Figure 3A, see the supporting information for compounds 451 and 459) showed the exclusive formation of the 1:1 TWJ/471 complex, regardless of the DNA:ligand ratio, and no interaction with 
ds17. These results highlighted a unique ligand binding site within the TWJ structure-most likely the branch point-and confirmed the exquisite TWJ-selectivity of 471. Similar experiments performed with 451 and 459 showed that the major species is the 1:1 TWJ/ligand complexes as well, along with traces of free DNA and 2:1 complexes, and highlighted also weak and random interactions with ds17 (since 1:1, 2:1 and 3:1 complexes could be detected). To further characterize and quantify these interactions, we calculated the equilibrium association constants (Table 2$):{ }^{39} \mathrm{~K}$ values confirmed the high affinity of 451, 459 and 471 for TWJ ( $\mathrm{K}$ between $3.9 \times 10^{6}$ and $1.9 \times 10^{9} \mathrm{M}^{-1}$ ) along with their excellent selectivity over duplex-DNA (>2-log difference).
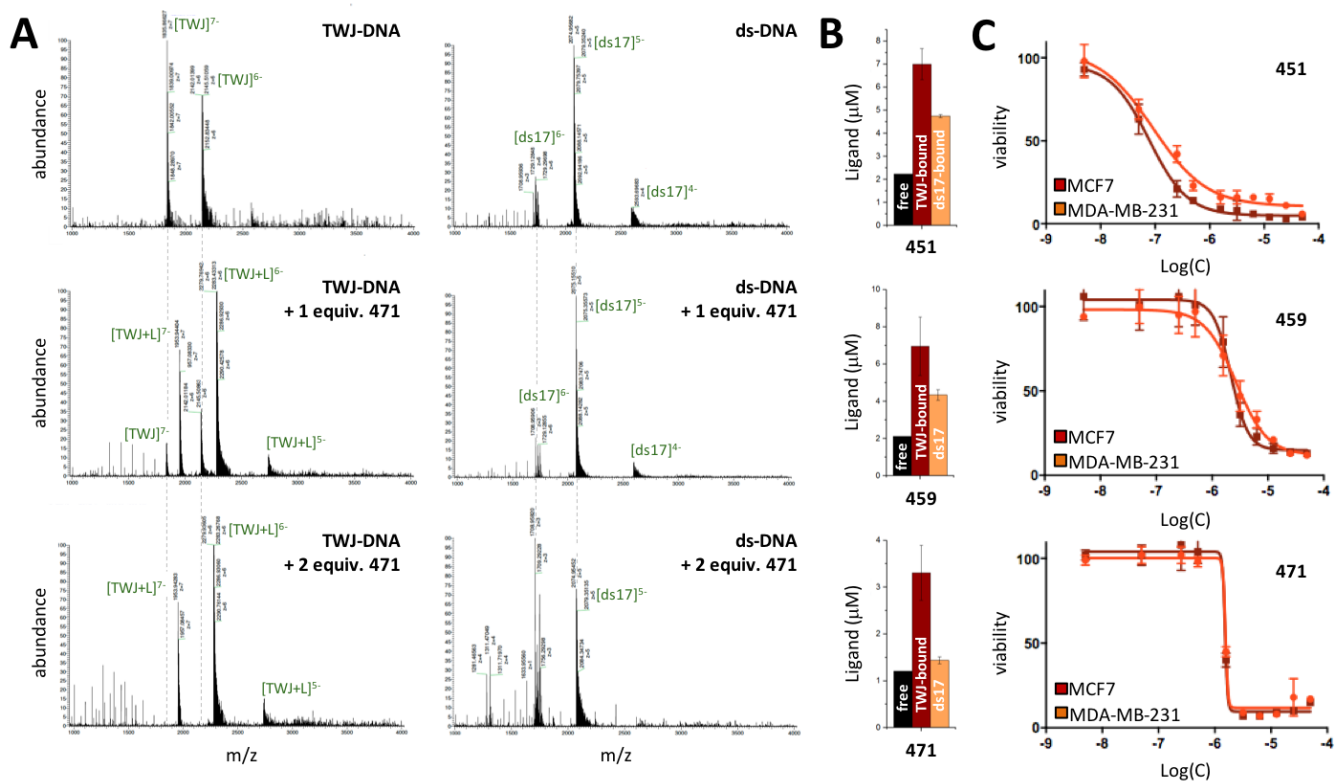

Figure 3. A. ESI-MS profiles of the association of TWJ (left panels) or ds17 (right panels) with increasing amounts (0, 1 and 2 mol. equiv.) of 471. Experiments performed with $5.0 \mu \mathrm{M}$ DNA, without or with 5.0 or $10 \mu \mathrm{M}$ ligand, in $100 \mathrm{mM}$ ammonium acetate, $\mathrm{pH} 7.2$, after 1-h equilibration at $25^{\circ} \mathrm{C}$. B. Equilibrium dialysis results for 451,459 and $\mathbf{4 7 1}$ (black bars: free ligand, brown bar: ligand bound to TWJ, orange bar: ligand bound to ds17). Experiments performed with $75 \mu \mathrm{M}$ DNA (base pairs), without or with $2 \mu \mathrm{M}$ ligand, in sodium phosphate $+100 \mathrm{mM} \mathrm{NaCl}, \mathrm{pH}$ 7.2, after 24-h equilibration at $25^{\circ} \mathrm{C}$. C. Viability profiles obtained via the SRB assay with $\mathbf{4 5 1 , 4 5 9}$ and 471 after 72 h-incubation $\left(37^{\circ} \mathrm{C}\right.$, DMEM) with MCF7 (brow line) and MDA-MB-231 (orange line) cells.

We next decided to confirm these results by an alternative technique, performed in solution, and selected the equilibrium dialysis (or competition dialysis) that has been already applied to a wide 
variety of DNA structures (single-stranded and double-stranded-DNA, triplex- and quadruplex-DNA), ${ }^{40}$ but not to DNA junctions. In this experiment, both TWJ and ds17, isolated from the main solution in semi-permeable chambers ( $200 \mu \mathrm{L}$ at $75 \mu \mathrm{M}$, expressed in base-pairs) were dialyzed against solution of ligands $(200 \mathrm{~mL}$ at $2 \mu \mathrm{M})$. After equilibration $\left(24 \mathrm{~h}, 25^{\circ} \mathrm{C}\right)$, the amount of ligand bound to each structure is quantified by fluorescence titration of the content of the dialysis chambers, after leaking the ligand by $1 \%$ sodium dodecyl sulfate SDS treatments (versus a quantification of the ligand remaining in the dialysis solution). Results presented in Figure 3B showed the preferred fixation of the ligands onto TWJ, but also emphasized the better selectivity of 471 as compared to 451 and 459 . Again, we quantified these interactions through the calculations of the apparent affinity constant $\mathrm{K}_{\mathrm{app}}$ (Table $2)::^{40}$ they confirmed the high affinity of $\mathbf{4 5 1}, \mathbf{4 5 9}$ and $\mathbf{4 7 1}$ for TWJ ( $\mathrm{K}_{\text {app }}$ between $6.0 \times 10^{6}$ and $1.4 \times 10^{7}$ $\mathrm{M}^{-1}$ ) along with their good (451 and 459) to excellent selectivity over duplex-DNA (>2-log difference for 471).

Preliminary cell-based assays with 451, 459 and $\mathbf{4 7 1}$. After the thorough evaluation of their TWJinteracting properties in vitro, we decided to evaluate the antiproliferative properties of 451, 459 and 471 against cancer cells. Their cellular activity was evaluated on two cancer cell lines, MCF7 and MDAMB-231, which are extensively used in the study of experimental therapeutics since they represent two different classes of breast cancers: MCF-7 are derived from a hormone-responsive cancer, expressing estrogen (ER), progesterone (PR) and glucocorticoid receptors (GR); MDA-MB-231 cells are representative of triple negative breast cancers (ER', $\mathrm{PR}^{-}$and HER2 (human epidermal growth factor receptor 2)), which are typically more aggressive and challenging to cure. In addition, MCF7 and MDAMB-231 are instrumental for the evaluation of DNA damaging agents since they have functional and mutant p53, respectively, a critical protein controlling DNA damage checkpoints and mediating cell cycle arrests and/or apoptosis in response to DNA damage. Viability analysis was performed here through the sulforhodamine $B(S R B)$ test ${ }^{41,42}$ and collected results were compared to the firmly established anticancer (and DNA damaging) agent camptothecin (Figure S4). ${ }^{43}$ To this end, cells were 
incubated for $72 \mathrm{~h}$ at $37{ }^{\circ} \mathrm{C}$ in DMEM without or with ligand, prior to fixation with a solution of trichloroacetic acid $10 \%\left(1 \mathrm{~h}\right.$ at $\left.4{ }^{\circ} \mathrm{C}\right)$. After supernatant removal, a solution of SRB $(0.2 \%$ in $1 \%$ acetic acid) was added for $30 \mathrm{~min}$ before being washed (acetic acid 1\%) and dried. A solution of Tris base (10 $\mathrm{mM}$ ) was then added to allow for optical density reading (at $530 \mathrm{~nm}$ ) to assess cell viability and determine the lethal dose $\left(\mathrm{LD}_{50}\right.$, the concentration at which $50 \%$ of the cell growth inhibition is reached).

Table 2. Quantification of DNA interactions (ESI-MS and dialysis) and toxicity (SRB) of top 3 TWJ-ligands.

\begin{tabular}{|c|c|c|c|c|c|c|c|c|c|}
\hline & \multicolumn{3}{|c|}{ ESI-MS $\left(K, \mathbf{M}^{-1}\right)^{\text {a }}$} & \multicolumn{2}{c|}{ Equilibrium dialysis $\left(K_{\text {app }}, M^{-1}\right)$} & \multicolumn{3}{c|}{ SRB test $\left(L_{50}, \mu M\right)$} \\
\hline ID & TWJ & ds & TWJ/ds & TWJ & ds & TWJ/ds & MCF7 & MDA & BJ-hTERT \\
\hline $\mathbf{4 5 1}$ & $4.7 \times 10^{7}$ & $7.5 \times 10^{4}$ & $>2-\log$ & $8.7 \times 10^{6}$ & $5.9 \times 10^{5}$ & $>1-\log$ & 0.10 & 0.16 & 0.04 \\
\hline $\mathbf{4 5 9}$ & $1.9 \times 10^{9}$ & $3.1 \times 10^{4}$ & $>4-\log$ & $1.4 \times 10^{7}$ & $3.8 \times 10^{5}$ & $>1-\log$ & 4.80 & 2.80 & 1.00 \\
\hline $\mathbf{4 7 1}$ & $3.9 \times 10^{6}$ & $7.5 \times 10^{3 *}$ & $>2-\log *$ & $6.0 \times 10^{6}$ & $4.7 \times 10^{4}$ & $>2-\log$ & 1.30 & 1.30 & 2.60 \\
\hline
\end{tabular}

${ }^{a} \mathrm{~K}$ calculations on the basis of experiments performed with $10 \mu \mathrm{M}$ DNA and $20 \mu \mathrm{M}$ ligands. * no ds17/471 interactions detected at 1:2 ratio; Ka calculated for experiments performed at 1:3 DNA/ligand ratio.

The results (Figure $3 \mathrm{C}$ and Table 2) showed that the cellular activity stood in the same range for both cells lines, with a higher inhibition properties for 451 (with $\mathrm{LD}_{50}=0.10$ and $0.16 \mu \mathrm{M}$ for MCF7 and MDA-MB-231, respectively), then for $471\left(\mathrm{LD}_{50}=1.30\right.$ and $\left.1.30 \mu \mathrm{M}\right)$ and for $459\left(\mathrm{LD}_{50}=4.80\right.$ and 2.80 $\mu \mathrm{M}$ ). In these conditions, 451 displayed a higher activity than camptothecin (with $\mathrm{LD}_{50}=1.70$ and 1.40 $\mu \mathrm{M})$, which is here found comparable to 471 . For sake of comparison, we also performed SRB investigations with normal fibroblasts (BJ-hTERT), as models of healthy cells. ${ }^{44}$ As seen in Table 2 , only 471 was found less toxic in BJ-hTERT than in cancer cells (2-fold difference, with $\mathrm{LD}_{50}=1.30$ and 2.60 $\mu \mathrm{M}$ for cancer cells and BJ-hTERT, respectively), making it the most promising compound from that series of ligands. To gain insights into the capacity of $\mathbf{4 7 1}$ to trigger DNA damage, we performed preliminary immunodetection studies using an antibody raised against the phosphorylated histone $\mathrm{H} 2 \mathrm{AX}$ (so called $\gamma \mathrm{H} 2 \mathrm{AX}$ ), an established marker of DNA damage. ${ }^{45}$ The pilot study was carried out with 
MCF7 treated with $\mathbf{4 7 1}$ and camptothecin as control. Collected images seen in Figure S5 confirmed that the ligands triggered a marked accumulation of $\gamma \mathrm{H} 2 \mathrm{AX}$ foci. These preliminary data thus provide an encouraging sign for the future of this new class of non-canonical DNA structure-targeting ligands as DNA damaging agents, and efforts are now invested to establish a firm link between cellular TWJ interaction and DNA damage.

\section{Conclusion.}

Compared to normal cells, cancer cells harbor a flawed repertoire of DNA damages signaling and repair capabilities, collectively known as DNA damage response, or DDR. ${ }^{1-6}$ Three main aspects of DDR differ from cancer to healthy cells: $i$ - the loss of one or more DDR pathways, ii- an increased level of replicative stress and iii- endogenous DNA damages. ${ }^{46}$ These aspects thus provide a window of therapeutic opportunities for compounds that trigger or exacerbate cellular crisis states. Our approach is here focused on compounds that stabilize three-way DNA junctions (TWJ), given that these higherorder DNA structures represent topological hindrances to polymerase that can hamper proper DNA transactions (replication, transcription). ${ }^{9}$ The TWJ-ligands could thus represent a novel and promising class of crisis-inducing agents.

To identify promising TWJ-ligands, we developed and report here on a validation framework that comprises 6 complementary in vitro assays: 1- the TWJ-Screen assay, which allowed for evaluating the ability to promote the TWJ folding of 1200 compounds; 2- a PAGE analysis, which confirms the TWJfolding ability of the 15 identified candidates in more stringent conditions; 3- the FRET-melting assay, which provide insights into both the TWJ-stabilizing properties and selectivity of the identified candidates; 4- an ESI-MS investigations, which further studied TWJ-selectivity and gives access to a quantification (affinity constants, $\mathrm{K}_{\mathrm{a}}$ ) of the ligand/DNA association; 5 - the equilibrium dialysis, which provides an alternative quantification of the ligand/DNA binding parameters; and 6- the SRB test, which assesses the antiproliferative activity of identified TWJ-ligands against human breast cancer cells (MCF7 and MDA-MB-231). 
Collectively, the wealth of data collected in the course of this study highlights the strength of our methodology to uncover TWJ-ligands, with the identification of 3 promising compounds here, i.e., 451, 459 and 471 , whose properties make them ideally suited to be used as prototype ligands throughout the validation chain. Exploring their use as anticancer agents will require to decipher the mechanisms underlying their antiproliferative properties. Also, our results highlight the need for screening wider chemical libraries to uncover ever more efficient TWJ-ligands and we are convinced that the framework described here is an ideal toolbox to do so. Importantly, libraries to be tested must not be focused on drug-like compounds or small-molecules only (like the Pathogen Box ${ }^{\circledR}$ or the CNE) but must include chemicals with defined shapes and volumes, given that it appears to be a major determinant of efficient TWJ-ligands. Indeed, thanks to the pioneering investigations of M. J. Hannon and coworkers performed with iron supramolecular cylinders, ${ }^{20-24}$ we known that the privileged binding site for compounds within the TWJ structure is the branch point, a cavity that results from the convergence of three duplex arms. This cavity is hydrophobic owing to its side-walls made of base-pairs (here two $\mathrm{T}=\mathrm{A}$ and one $\mathrm{G} \equiv \mathrm{C}$ base pairs), thus being suited to accommodate sterically demanding ligands displaying large aromatic moieties. This was confirmed here through the unveiling of 3 promising candidates, the azacyclophanes 451 and 459 (1,5-BisNP-O and 2,7-BisA-O, respectively) and the azacryptand 471 (3,3'TrisBP), which all display well-defined three-dimensional structures and large aromatic moieties (naphthalene, acridine and bipyridine) prone to interact efficiently with the cavity walls. These results thus provide new perspectives on and further insights into the cellular activity of the azacyclophanes and azacryptands, which could originate in multiple dysregulated pathways (TWJ-interaction as well as interactions with abasic sites and cleavage and inhibition of DNA repair). ${ }^{47,48}$ They also contribute to expand the portfolio of DNA binders with promising anticancer properties and the panoply of DNA structure targets with high therapeutic value. 


\section{Experimental section}

Chemicals. The open access Pathogen Box ${ }^{\circledR}$ comprises 400 compounds with biological activity against specific pathogenic organisms. The box is provided by the Medicines for Malaria Venture as an open access compound collection (http://www.pathogenbox.org/). The chimiothèque nationale essentielle is a collection of 640 compounds assembled by and purchased from the French National chemolibrary (http://chimiotheque-nationale.cn.cnrs.fr/). All other chemicals have been prepared according to methodologies described (with purity $\geq 95 \%$ as evaluated by elemental analyses or HPLCMS) in the corresponding references, except camptothecin $(99.8 \%$ purity), purchased from Selleckchem.

Table 3. Oligonucleotides used in this study

\begin{tabular}{|c|c|c|c|}
\hline Status & Nature & Name & Sequence \\
\hline \multirow[t]{3}{*}{ Labeled } & \multirow[t]{3}{*}{ TWJ } & FAM-TWJ-S1 & FAM-d $\left[{ }^{5} \mathrm{CG}_{2} \mathrm{~A}_{2} \mathrm{CG}_{2} \mathrm{CACTCG}^{3}\right]$ \\
\hline & & TWJ-S3-TAMRA & $\mathrm{d}\left[{ }^{5^{\prime}} \mathrm{C}_{2} \mathrm{ACGCTCGT}_{2} \mathrm{C}_{2} \mathrm{G}^{3^{\prime}}\right]$-TAMRA \\
\hline & & F-TWJ-T & FAM-d $\left[{ }^{5} \mathrm{~A}(\mathrm{CT})_{2}(\mathrm{TC})_{2} \mathrm{G}-\mathrm{T}_{6}-\mathrm{C}(\mathrm{GA})_{2}\right.$ GCGAC-T ${ }_{6}$ GTCGC $\left.(\mathrm{AG})_{2} \mathrm{~T}^{3}\right]$-TAMRA \\
\hline \multirow[t]{7}{*}{ Unlabeled } & \multirow[t]{4}{*}{ TWJ } & TWJ-S1 & $\mathrm{d}\left[\left[^{5} \mathrm{CG}_{2} \mathrm{~A}_{2} \mathrm{CG}_{2} \mathrm{CACTCG}^{3}\right]\right.$ \\
\hline & & TWJ-S2 & $\left.\mathrm{d}^{5^{\prime}} \mathrm{CGAGTGCAGCGTG}_{2}{ }^{3}\right]$ \\
\hline & & TWJ-S3 & $\left.\mathrm{d}^{5}{ }^{5} \mathrm{C}_{2} \mathrm{ACGCTCGT}_{2} \mathrm{C}_{2} \mathrm{G}^{3}\right]-$ \\
\hline & & TWJ & $\mathrm{d}\left[{ }^{5} \mathrm{~A}(\mathrm{CT})_{2}(\mathrm{TC})_{2} \mathrm{G}-\mathrm{T}_{6}-\mathrm{C}(\mathrm{GA})_{2} \mathrm{GCGAC}-\mathrm{T}_{6}-\mathrm{GTCGC}(\mathrm{AG})_{2} \mathrm{~T}^{3}\right]$ \\
\hline & \multirow[t]{3}{*}{ duplex } & $\begin{array}{l}\text { ds12 } \\
\text { self-complementary }\end{array}$ & $\begin{array}{l}\left.\text { strand 1: } \mathrm{d}^{5^{\prime}} \mathrm{CGCGA}_{2} \mathrm{~T}_{2} \mathrm{CGCG}^{3}{ }^{\prime}\right] \\
\left.\text { strand 2: } \mathrm{d}^{5^{\prime}} \mathrm{CGCGA}_{2} \mathrm{~T}_{2} \mathrm{CGCG}^{3^{\prime}}\right]\end{array}$ \\
\hline & & ds17 & $\begin{array}{l}\text { strand 1: } \mathrm{d}\left[{ }^{5^{\prime}} \text { CCAGTTCGTAGTAACCC }{ }^{3^{\prime}}\right] \\
\left.\text { strand 2: } \mathrm{d}^{5^{\prime}} \text { GGGTTACTACGAACTGG }{ }^{3^{\prime}}\right]\end{array}$ \\
\hline & & $\begin{array}{l}\mathrm{ds} 26 \\
\text { self-complementary }\end{array}$ & $\begin{array}{l}\left.\text { strand 1: } \mathrm{d}^{5^{\prime}} \text { CAATCGGATCGAATTCGATCCGATTG }{ }^{3^{3}}\right] \\
\left.\text { strand 2: } \mathrm{d}^{5^{\prime}} \text { GTTAGCCTAGCTTAAGCTAGGCTAAC }{ }^{3^{3}}\right]\end{array}$ \\
\hline
\end{tabular}

Oligonucleotides. The lyophilized DNA sequences (Table 3), purchased from Eurogentec ${ }^{\mathrm{TM}}$ (Seraing, Belgium) were firstly diluted at $500 \mu \mathrm{M}$ in deionized water (18.2 M. $\mathrm{cm}$ resistivity). The actual concentration of each DNA solution was determined after a dilution to $1 \mu \mathrm{M}$ theoretical concentration through UV spectral analysis at $260 \mathrm{~nm}$ (after $5 \mathrm{~min}$ at $90^{\circ} \mathrm{C}$ ) with the molar extinction coefficient values provided by the manufacturer. Separated strands (FAM-TWJ-S1, TWJ-S1, TWJ-S2, TWJ-S3TAMRA and TWJ-S3) were subsequently diluted in a CacoK buffer (10 mM lithium cacodylate buffer plus $10 \mathrm{mM} \mathrm{KCl} / 90 \mathrm{mM} \mathrm{LiCl} \mathrm{pH} \mathrm{7.2)} \mathrm{at} 2 \mu \mathrm{M}$ for TWJ-Screen and $9 \mu \mathrm{M}$ for PAGE experiments. For FRETmelting experiments, the higher-order DNA structures of both FAM-TWJ-TAMRA and ds26 were 
prepared by mixing $40 \mu \mathrm{L}$ of the constitutive strand (500 $\mu \mathrm{M})$ with $8 \mu \mathrm{L}$ of a lithium cacodylate buffer solution (100 mM, pH 7.2), plus $8 \mu \mathrm{L}$ of a $\mathrm{KCl} / \mathrm{LiCl}$ solution $(100 \mathrm{mM} / 900 \mathrm{mM})$ and $24 \mu \mathrm{L}$ of water. For ESI-MS analysis, the higher-order DNA structure was prepared by mixing $17 \mu \mathrm{L}$ of TWJ (500 $\mu \mathrm{M}$ ) with $17 \mu \mathrm{L}$ of ammonium acetate buffer $(1 \mathrm{M}, \mathrm{pH} 7.0)$ and $136 \mu \mathrm{L}$ of water. The higher-order structures were folded according to two procedures: (a) for FAM-TWJ-TAMRA (FRET-melting) and TWJ (ESI-MS), solutions were heated $\left(90^{\circ} \mathrm{C}, 5 \mathrm{~min}\right.$ ), cooled on ice (FRET-melting) or to $25^{\circ} \mathrm{C}$ gradually (ESI-MS) and then stored at least overnight $\left(4^{\circ} \mathrm{C}\right)$; (b) for $\mathrm{ds} 26$, the solutions were heated $\left(90^{\circ} \mathrm{C}, 5 \mathrm{~min}\right)$, gradually cooled $\left(65,60,55,50,40\right.$ and $\left.30^{\circ} \mathrm{C}(60 \mathrm{~min} / \mathrm{step}), 25^{\circ} \mathrm{C}(2 \mathrm{~h})\right)$ and then stored overnight $\left(4^{\circ} \mathrm{C}\right)$.

TWJ-Screen assay. Experiments are performed in a 96-well format plate (Greiner, F-bottom black) using a BMG Labtech ClarioStar equipped with FAM filters ( $\lambda$ ex $=492 \mathrm{~nm} ; \lambda$ em $=516 \mathrm{~nm}$ ) at $37^{\circ} \mathrm{C}$. Experiments are performed in CacoK buffer (10 mM lithium cacodylate plus $10 \mathrm{mM} \mathrm{KCl} / 90 \mathrm{mM} \mathrm{LiCl}$, pH 7.2, final volume: $100 \mu \mathrm{L} /$ well) with $1 \mu \mathrm{M}$ ligand (10 $\mu \mathrm{L}$ of $10 \mu \mathrm{M}$ solution) and $0.2 \mu \mathrm{M}$ DNA (stepwise addition of $10 \mu \mathrm{L}$ of $2 \mu \mathrm{M}$ solution of FAM-TWJ-S1, TWJ-S2 and TWJ-S3-TAMRA). The microplate is centrifuged quickly (30 s) and then placed into the ClarioStar. The FAM fluorescence is monitored upon gentle stirring at $37^{\circ} \mathrm{C}$ every 5 min during $1 \mathrm{~h}$. Final data are analyzed by using Excel (Microsoft Corp.) and OriginPro ${ }^{\circledR 9}$ (OriginLab Corp.): the results are expressed as normalized fluorescence intensity (NFI) values collected at $60 \mathrm{~min}$. The efficiency of ligands to fold TWJ is quantified by comparing the NFI of FAM-TWJ-S1 alone (defined as 100\%) versus that of [FAM-TWJS1+ligand] (for discarding unwarranted ligand's interaction with FAM-TWJ-S1) on one hand, and the NFI of the mixture M ([FAM-TWJ-S1+TWJ-S2+TWJ-S3-TAMRA]) versus [M+ligand] (that quantifies the TWJ folding per se) on the other hand. Reported NFI values are means of 3 experiments.

FRET-melting assay. Experiments are performed in a 96-well format plate (Agilent) using an Agilent Stratagene Mx3005P equipped with FAM filters ( $\lambda$ ex $=492 \mathrm{~nm} ; \lambda$ em $=516 \mathrm{~nm}$ ) from $25{ }^{\circ} \mathrm{C}$ to $90{ }^{\circ} \mathrm{C}$. Experiments are performed in CacoK buffer (10 mM lithium cacodylate plus $10 \mathrm{mM} \mathrm{KCl} / 90 \mathrm{mM} \mathrm{LiCl}$, 
pH 7.2, final volume: $100 \mu \mathrm{L} /$ well) with $0.2 \mu \mathrm{M}$ DNA (the labelled sequence FAM-TWJ-TAMRA and with $1 \mu \mathrm{M}$ ligand ( $1 \mu \mathrm{L}$ of $100 \mu \mathrm{M}$ solution). The microplate is centrifuged quickly (10 s), gently stirred for $30 \mathrm{~min}$ at $25^{\circ} \mathrm{C}$, centrifuged quickly $(10 \mathrm{~s})$ again and then placed into the Mx3005P. After a first equilibration step $\left(25^{\circ} \mathrm{C}, 30 \mathrm{~s}\right)$, a stepwise increase of $1{ }^{\circ} \mathrm{C}$ every $30 \mathrm{~s}$ for $65 \mathrm{cycles}$ to reach $90^{\circ} \mathrm{C}$ was performed, and measurements were made after each cycle. Final data were analyzed with Excel and OriginPro ${ }^{\circledR}$. The emission of FAM was normalized ( 0 to 1 ), and $T_{1 / 2}$ was defined as the temperature for which the normalized emission is 0.5 ; reported $\Delta \mathrm{T}_{1 / 2}$ values are means of 3 experiments. Competitive experiments are performed similarly, that is, with labelled DNA (FAM-TWJ-5dhp-TAMRA, $0.2 \mu \mathrm{M})$ in presence of ligand (1.0 $\mu \mathrm{M}, 5$ mol. equiv.) and increasing amounts (3.0 and $10.0 \mu \mathrm{M}, 15$ and 50 mol. equiv.) of the unlabeled competitor ds26.

Polyacrylamide gel electrophoresis. Non-denaturing polyacrylamide gel electrophoresis (PAGE) was performed according to the protocol described by J. Malina et $a .^{22}$, in $15 \%$ polyacrylamide gel (prepared by mixing $6.8 \mathrm{~mL}$ of acrylamide (40\%), $11.2 \mathrm{~mL}$ of TBE buffer, $180 \mu \mathrm{L}$ of APS (10\% w/v) and $18 \mu \mathrm{L}$ of TEMED; 15 min-polymerization). Samples were prepared in $15 \mu \mathrm{L}$ (volume) comprising $15 \mu \mathrm{L}$ DNA or DNA/ligand mixes plus $3 \mu \mathrm{L}$ of DNA loading dye (6X). Each solution was prepared separately: TWJ-S1 alone (6 $\mu \mathrm{M})$, [TWJ-S1+TWJ-S2+TWJ-S3] (or M) $(6 \mu \mathrm{M})$, [M $(6 \mu \mathrm{M})+1$ mol. equiv. ligand $(6 \mu \mathrm{M})]$, [M $(6 \mu \mathrm{M})+2$ mol. equiv. ligand $(12 \mu \mathrm{M})]$, [M $(6 \mu \mathrm{M})+3$ mol. equiv. ligand $(18 \mu \mathrm{M})]$, [M $(6 \mu \mathrm{M})+5 \mathrm{~mol}$. equiv. ligand $(30 \mu \mathrm{M})$ ] and [TWJ-S1+TWJ-S2] $(6 \mu \mathrm{M})$; the solutions were stirred for 1 hour at $25^{\circ} \mathrm{C}$ prior the addition of $3 \mu \mathrm{L}$ of DNA loading dye (6X). These mixes were stirred for $15 \mathrm{~min}$ at $25{ }^{\circ} \mathrm{C}$ (a period during which the gel is stacked at $7 \mathrm{~W}(150-180 \mathrm{~V}, 43-38 \mathrm{~mA})$ in TBE buffer enriched with $100 \mathrm{mM} \mathrm{NaCl}$, $\mathrm{pH}$ 8.3) prior the loading of $12 \mu \mathrm{L} /$ well of each solution and $1 \mathrm{~h}$-migration at $7 \mathrm{~W}$. After the migration, gels were analyzed after a post-staining step (SYBR ${ }^{\circledR}$ Gold solution, $1: 10000,10 \mathrm{~min}, 25^{\circ} \mathrm{C}$ under gentle agitation) with a UVP MultiDoc-It ${ }^{\circledR}$ imaging system ( $\lambda$ ex $=302 \mathrm{~nm}$ ). Competitive PAGE experiments were performed according to a similar protocol but including FAM-TWJ-S1 (instead of the unlabeled TWJ-S1). $15 \mu \mathrm{L}$ of following solutions were prepared: ds12 alone (Table 3) alone ( $252 \mu \mathrm{M}-\mathrm{nt}$ ), $\mathrm{M}$ alone 
(252 $\mu \mathrm{M}-\mathrm{nt})$, [M (252 $\mu \mathrm{M}-\mathrm{nt})+2$ mol. equiv. ligand $(12 \mu \mathrm{M})]$, [M (252 $\mu \mathrm{M}-\mathrm{nt})+2$ mol. equiv. ligand (12 $\mu \mathrm{M})+1$ mol. equiv. ds12 (252 $\mu \mathrm{M}-\mathrm{nt})]$, [M $(252 \mu \mathrm{M}-\mathrm{nt})+2$ mol. equiv. ligand $(12 \mu \mathrm{M})+5$ mol. equiv. ds12 (1260 $\mu \mathrm{M}-\mathrm{nt})]$, [M $(252 \mu \mathrm{M}-\mathrm{nt})+2$ mol. equiv. ligand $(12 \mu \mathrm{M})+10$ mol. equiv. ds12 $(2520 \mu \mathrm{M}-$ nt)]. The solutions were stirred for 1 hour at $25{ }^{\circ} \mathrm{C}$ prior the addition of $3 \mu \mathrm{L}$ of sucrose $48 \%$. These mixes were stirred for $15 \mathrm{~min}$ at $25^{\circ} \mathrm{C}$ prior the loading of $12 \mu \mathrm{L} /$ well of each solution and 50 minutes migration at $7 \mathrm{~W}$. After the migration, gels were post-stained (SYBR ${ }^{\circledR}$ Gold solution, 1:10000) and imaged with the MultiDoc-It ${ }^{\circledR}(\lambda e x=302 \mathrm{~nm})$.

ESI-MS analysis. Electrospray mass spectrometry experiments were performed on a LTQ Orbitrap XL (Thermo Scientific) spectrometer equipped with Ion Max source and HESI-II probe in the negative ion mode. TWJ and ds17 alone as well as the corresponding DNA:ligand mixtures (1:1 and 1:2 mol. equiv.) were prepared in $100 \mathrm{mM}$ ammonium acetate buffer and equilibrated at $25^{\circ} \mathrm{C}$ for 1 hour. To obtain a stable electrospray signal, $20 \%$ of methanol were added to the solution just before injection. The solutions were injected with syringe pump at a flow rate of $5 \mu \mathrm{L} / \mathrm{min}$. The full scan mass was recorded in 600-4000 $\mathrm{m} / \mathrm{z}$ range. The following tuning parameters were used: heater temperature $=$ $50{ }^{\circ} \mathrm{C}$, spray voltage $=4.0 \mathrm{kV}$, capillary temperature $=275^{\circ} \mathrm{C}$, Tube lens $=-160.00$ (negative ion mode) and the capillary voltage varied between $-35.00 \mathrm{~V}$ and $-60.00 \mathrm{~V}$. Quantification of the equilibrium affinity constants (K) of ligands for either TWJ or ds17 has been done according to the procedure described by F. Rosu et al. $^{39}$

Competition Equilibrium Dialysis. The oligonucleotide solutions of TWJ and ds17 were prepared as $75 \mu \mathrm{M}$ (base pair) concentration in $111 \mathrm{mM} \mathrm{NaCl}$ solution. These solutions were then heated at $90^{\circ} \mathrm{C}$ for 5 minutes, cooled down slowly to $25^{\circ} \mathrm{C}$ and left at $4{ }^{\circ} \mathrm{C}$ overnight. For each dialysis experiment were used four dialysis units (Slide-A-Lyzer ${ }^{\circledR}$ MINI Dialysis Units, molecular weight cut-off: 3.5 kDa) previously washed with milli-Q water. Two of them were filled with $200 \mu \mathrm{L}$ of TWJ DNA solution and the other two bags with $200 \mu \mathrm{L}$ of the solution of duplex DNA ds17. Dialysis units were then placed 
into a beaker containing $200 \mathrm{~mL}$ of $2-2.5 \mu \mathrm{M}$ solution of tested ligand enriched with $111 \mathrm{mM}$ of $\mathrm{NaCl}$, covered with parafilm and aluminum foil and allowed to equilibrate for $24 \mathrm{~h}$ at room temperature. The solutions from each dialysis unit were then transferred to Eppendorf tubes. The content of each bag was then mixed with sodium dodecyl sulfate solution (10\%) to reach a $1 \%$ SDS concentration $(\mathrm{v} / \mathrm{v})$. The concentrations of free product in the dialysate solution and product concentrations in the dialysis bags were determined by fluorescence measurements using the molar extinction coefficients of the ligand (determined in the presence and absence of the detergent, see Tables 4 and 5 respectively) and finally, the apparent association constants $\left(\mathrm{K}_{\mathrm{app}}\right)$ were calculated according to formula: $:^{40} \mathrm{~K}_{\mathrm{app}}=[\mathrm{L}-\mathrm{NA}] /[\mathrm{NA}][\mathrm{L}]$, expressed in $\mathrm{M}^{-1}$, in which [L-NA] is the concentration of ligand bound to nucleic acid determined as a difference between total ligand concentration inside the dialysis unit and free ligand concentration (dialysate solution); [NA] is the concentration of free DNA calculated as a difference between initial concentration of nucleic acid and [L-NA]; and [L] is the free ligand concentration (dialysate solution).

Table 4. Extinction coefficients of tested ligands.

\begin{tabular}{|c|c|c|c|}
\hline Ligand & $\begin{array}{c}\text { Excitation } \\
\text { wavelength }\end{array}$ & $\begin{array}{c}\text { Emission } \\
\text { wavelength }\end{array}$ & $\begin{array}{c}\text { Molar Fluorescence Extinction Coefficient } \\
{\left[\mathrm{mol}^{-1} \cdot \mathrm{L}^{-1} \cdot \mathrm{cm}^{-1}\right]}\end{array}$ \\
\hline 451 & $285 \mathrm{~nm}$ & $330 \mathrm{~nm}$ & $2.33 \cdot 10^{9}$ \\
\hline 459 & $300 \mathrm{~nm}$ & $400 \mathrm{~nm}$ & $4.74 \cdot 10^{8}$ \\
\hline 471 & $200 \mathrm{~nm}$ & $319 \mathrm{~nm}$ & $9.38 \cdot 10^{8}$ \\
\hline
\end{tabular}

Table 5. Molar fluorescent extinction coefficients of tested ligands.

\begin{tabular}{|c|c|c|c|}
\hline Ligand & $\begin{array}{c}\text { Excitation } \\
\text { wavelength }\end{array}$ & $\begin{array}{c}\text { Emission } \\
\text { wavelength }\end{array}$ & $\begin{array}{c}\text { Molar Fluorescence Extinction Coefficient } \\
{\left[\mathbf{m o l}^{-1} \cdot \mathrm{L}^{-1} \cdot \mathrm{cm}^{-1}\right]}\end{array}$ \\
\hline 451 & $285 \mathrm{~nm}$ & $335 \mathrm{~nm}$ & $3.91 \cdot 10^{9}$ \\
\hline 459 & $300 \mathrm{~nm}$ & $400 \mathrm{~nm}$ & $1.07 \cdot 10^{9}$ \\
\hline 471 & $200 \mathrm{~nm}$ & $318 \mathrm{~nm}$ & $6.58 \cdot 10^{8}$ \\
\hline
\end{tabular}

Cell Culture. MCF7 (breast adenocarcinoma) and MDA-MB-231 (breast adenocarcinoma) cells were routinely cultured in $75 \mathrm{~cm}^{2}$ tissue culture flasks ( $\mathrm{Nunc}^{\mathrm{TM}}$ ) at $37^{\circ} \mathrm{C}$ in a humidified, $5 \% \mathrm{CO} 2$ atmosphere in Dulbecco's Modified Eagle Medium (DMEM) supplemented with 10\% fetal bovine serum (FBS, Gibco) and 1\% Penicillin-Streptomycin (Pen-Strep, 5.0 u.mL-1 Pen/5.0 $\mu$ g.mL-1 Strep, Gibco) mixture. Same culture conditions were used for BJ-hTERT, normal foreskin fibroblasts immortalized by hTERT 
transduction, except that the growth medium was a 4:1 mixture of DMEM and M199 medium supplemented with 15\% FBS and Pen-Strep. Cells were subcultured twice a week using a standard protocol: the medium was first removed by aspiration; the cells were subsequently washed once with Dulbecco's Phosphate Buffered Saline (DPBS) and $1.5 \mathrm{~mL}$ of a trypsin solution (0.25\%, Gibco) was added. After $5 \mathrm{~min}$ at $37{ }^{\circ} \mathrm{C}$, cells were manually harvested and $500 \mu \mathrm{L}$ of the solution of cells in suspension was dispensed into three cell culture flasks containing $10 \mathrm{~mL}$ of DMEM medium (with $10 \%$ FBS and $1 \%$ Pen-Strep).

Cell proliferation SRB assay. The antiproliferative properties of the ligands were assessed through the sulforhodamine-B (SRB) assay, according to the protocols described by V. Vichai \& K. Kirtikara and P. Skehan et al. ${ }^{41,42}$ Cells were seeded in a 96-well plate (6000 cells/well) in $160 \mu \mathrm{L}$ of growth medium for $24 \mathrm{~h}$ at $37^{\circ} \mathrm{C}$. Then, $40 \mu \mathrm{L}$ of ligand solution were added to reach the final concentration of the ligands between 500 and $0.05 \mu \mathrm{M}$ or 50 and $0.005 \mu \mathrm{M}$ and incubated for $72 \mathrm{~h}$ at $37^{\circ} \mathrm{C}$. After $72 \mathrm{~h}$, the media was removed and the cells fixed with a solution of trichloroacetic acid $10 \%\left(150 \mu \mathrm{L}, 1 \mathrm{~h}\right.$ at $\left.4{ }^{\circ} \mathrm{C}\right)$. The supernatant was removed, the fixed cells were washed with water and then dried. A solution 100 $\mu \mathrm{L}$ of SRB $(0.2 \%$ in $1 \%$ acetic acid) was added into each well (except control wells); after $30 \mathrm{~min}$, the supernatant was removed, the wells were washed 3 times with $150 \mu \mathrm{L}$ of acetic acid (1\%) and dried. After that, $150 \mu \mathrm{L}$ of Tris base $(10 \mathrm{mM})$ were added in each well and the microplate gently stirred for $5 \mathrm{~min}$ at $25^{\circ} \mathrm{C}$. Optical density (OD) values were determined at $530 \mathrm{~nm}$. Final data were analyzed with Excel (Microsoft Corp.) and GraphPad7.0 (Prism software): the $\mathrm{OD}_{530 \mathrm{~nm}}$ was normalized (from 0 to 100; 0 for ligand untreated, SRB unstained cells and 100 for ligand untreated, SRB stained cells), and $\mathrm{LD}_{50}$ (lethal dose, defined as the concentration at which $50 \%$ of the cell growth inhibition is reached) determined for a normalized $\mathrm{OD}_{530 \mathrm{~nm}}$ of $50 \%$; reported $\mathrm{LD}_{50}$ values are means of 3 experiments. 


\section{ASSOCIATED CONTENT}

\section{Supporting information}

The Supporting Information is available free of charge on the ACS Publication website at DOI: 10.1021/acs.jmed- chem.

Additional figures regarding ESI-MS evaluations of 451, 459 and 471 with both TWJ-DNA and ds-DNA (Figures S1-S3), SRB assays performed with MCF7 and MDA-MB-231 cells and camptothecin, and with BJ-hTERT and 451, 459, 471 and camptothecin (Figure S4) and immunodetection experiments performed with MCF7 cells and $\mathbf{4 7 1}$ and camptothecin (Figure S5), as well as two additional files comprising the complete TWJ-screen results and the molecular formula strings.

\section{AUTHOR INFORMATION}

\section{Corresponding authors}

*E-mail: david.monchaud@cnrs.fr

\section{ORCID}

Charles H. Devillers: 0000-0001-9078-7035

Anton Granzhan: 0000-0002-0424-0461

Marie-Paule Teulade-Fichou: 0000-0002-2053-7513

Murielle Chavarot-Kerlidou: 0000-0003-2709-3772

Bruno Therrien: 0000-0002-0388-2745

Sébastien Britton: 0000-0002-7008-5316

David Monchaud: 0000-0002-3056-9295

\section{Funding}

This project has received funding from the European Union's Horizon 2020 research and innovation program (grant agreement H2020-MSCA-IF-2016-750368), from the Agence Nationale de la Recherche (grant agreement ANR-17-CE17-0010-01), IDEX Paris Saclay ('IDI 2016', ANR-11-IDEX-0003-02) and is 
also part of the project "Pharmacoimagerie \& agents théranostiques" supported by the Université de Bourgogne and Conseil Régional de Bourgogne (PARI) and the European Union (PO FEDER-FSE Bourgogne 2014/2020 programs).

\section{Acknowledgments.}

The authors thank Medicines for Malaria Venture for the Pathogen Box ${ }^{\circledR}$ and the French National Chemical Library for the CNE, as well as R. A. Weinberg for the gift of the BJ-hTERT cell line.

\section{Notes}

The authors declare no competing financial interest.

\section{ABBREVIATION}

DNA, deoxyribonucleic acid; TWJ, three-way DNA junction; PAGE, polyacrylamide gel electrophoresis; FRET, fluorescence resonance energy transfer; ESI-MS, electrospray ionization mass spectrometry; SRB, sulforhodamine B; ROS, reactive oxygen species; HTS, high-throughput screen; MMV, Medicines for Malaria Venture; CNE, chimiothèque nationale essentielle; ICMUB, institut de chimie moléculaire de l'université de Bourgogne; FAM, fluorescein amidite; TAMRA, tetramethylrhodamine amidite; NFI, normalized FAM intensity; SDS, sodium dodecyl sulfate; LD, lethal dose; DDR: DNA damage response; DMEM , Dulbecco's Modified Eagle Medium; FBS, fetal bovine serum; OD, optical density.

\section{REFERENCES}

1. Zeman, M. K.; Cimprich, K. A. Causes and consequences of replication stress. Nat. Cell Biol. 2014, $16,2-9$.

2. Técher, H.; Koundrioukoff, S.; Nicolas, A.; Debatisse, M. The impact of replication stress on replication dynamics and DNA damage in vertebrate cells. Nat. Rev. Genet. 2017, 18, 535-550.

3. Gaillard, H.; García-Muse, T.; Aguilera, A. Replication stress and cancer. Nat. Rev. Cancer 2015, 15, 276-289. 
4. Dobbelstein, M.; Sørensen, C. S. Exploiting replicative stress to treat cancer. Nat. Rev. Drug Discovery 2015, 14, 405-423.

5. Jackson, S. P.; Bartek, J. The DNA-damage response in human biology and disease. Nature 2009, $461,1071-1078$.

6. Ciccia, A.; Elledge, S. J. The DNA damage response: making it safe to play with knives. Mol. Cell 2010, 40, 179-204.

7. Rodriguez, R.; Miller, K. M. Unravelling the genomic targets of small molecules using highthroughput sequencing. Nat. Rev. Genet. 2014, 15, 783-796.

8. Helleday, T.; Petermann, E.; Lundin, C.; Hodgson, B.; Sharma, R. A. DNA repair pathways as targets for cancer therapy. Nat. Rev. Cancer 2008, 8, 193-204.

9. Mirkin, E. V.; Mirkin, S. M. Replication fork stalling at natural impediments. Microbiol. Mol. Biol. Rev. 2007, 71, 13-35.

10. Zhao, J.; Bacolla, A.; Wang, G.; Vasquez, K. M. Non-B DNA structure-induced genetic instability and evolution. Cell. Mol. Life Sci. 2010, 67, 43-62.

11. Caruthers, J. M.; McKay, D. B. Helicase structure and mechanism. Curr. Opin. Struct. Biol. 2002, $12,123-133$.

12. Zimmer, J.; Tacconi, E. M.; Folio, C.; Badie, S.; Porru, M.; Klare, K.; Tumiati, M.; Markkanen, E.; Halder, S.; Ryan, A. Targeting BRCA1 and BRCA2 deficiencies with G-quadruplex-interacting compounds. Mol. Cell 2016, 61, 449-460.

13. Xu, H.; Di Antonio, M.; McKinney, S.; Mathew, V.; Ho, B.; O’Neil, N. J.; Dos Santos, N.; Silvester, J.; Wei, V.; Garcia, J. CX-5461 is a DNA G-quadruplex stabilizer with selective lethality in BRCA1/2 deficient tumours. Nat. Commun. 2017, 8, 14432.

14. Lemmens, B.; Van Schendel, R.; Tijsterman, M. Mutagenic consequences of a single G-quadruplex demonstrate mitotic inheritance of DNA replication fork barriers. Nat. Commun. 2015, 6, 8909.

15. Bochman, M. L.; Paeschke, K.; Zakian, V. A. DNA secondary structures: stability and function of Gquadruplex structures. Nat. Rev. Genet. 2012, 13, 770-780. 
16. Hänsel-Hertsch, R.; Di Antonio, M.; Balasubramanian, S. DNA G-quadruplexes in the human genome: detection, functions and therapeutic potential. Nat. Rev. Mol. Cell Biol. 2017, 18, 279.

17. Vuong, S.; Stefan, L.; Lejault, P.; Rousselin, Y.; Denat, F.; Monchaud, D. Identifying three-way DNA junction-specific small-molecules. Biochimie 2012, 94, 442-450.

18. Novotna, J.; Laguerre, A.; Granzhan, A.; Pirrotta, M.; Teulade-Fichou, M.-P.; Monchaud, D. Cationic azacryptands as selective three-way DNA junction binding agents. Org. Biomol. Chem. $2015,13,215-222$.

19. Guyon, L.; Pirrotta, M.; Duskova, K.; Granzhan, A.; Teulade-Fichou, M.-P.; Monchaud, D. TWJScreen: an isothermal screening assay to assess ligand/DNA junction interactions in vitro. Nucleic Acids Res. 2018, 46, e16.

20. Oleksi, A.; Blanco, A. G.; Boer, R.; Usón, I.; Aymamí, J.; Rodger, A.; Hannon, M. J.; Coll, M. Molecular recognition of a three-way DNA junction by a metallosupramolecular helicate. Angew. Chem. Int. Ed. 2006, 45, 1227-1231.

21. Cerasino, L.; Hannon, M. J.; Sletten, E. DNA three-way junction with a dinuclear iron (II) supramolecular helicate at the center: A NMR structural study. Inorg. Chem. 2007, 46, 6245-6251.

22. Malina, J.; Hannon, M. J.; Brabec, V. Recognition of DNA three-way junctions by metallosupramolecular cylinders: gel electrophoresis studies. Chem. Eur. J. 2007, 13, 3871-3877.

23. Hotze, A. C.; Hodges, N. J.; Hayden, R. E.; Sanchez-Cano, C.; Paines, C.; Male, N.; Tse, M.-K.; Bunce, C. M.; Chipman, J. K.; Hannon, M. J. Supramolecular iron cylinder with unprecedented DNA binding is a potent cytostatic and apoptotic agent without exhibiting genotoxicity. Chem. Biol. $2008,15,1258-1267$

24. Boer, D. R.; Kerckhoffs, J. M.; Parajo, Y.; Pascu, M.; Usón, I.; Lincoln, P.; Hannon, M. J.; Coll, M. Self-Assembly of functionalizable two-component 3D DNA arrays through the induced formation of DNA three-way-Junction branch points by supramolecular cylinders. Angew. Chem. Int. Ed. 2010, 49, 2336-2339. 
25. Barros, S. A.; Chenoweth, D. M. Recognition of nucleic acid junctions using triptycene-based molecules. Angew. Chem., Int. Ed. 2014, 53, 13746-13750.

26. Barros, S. A.; Chenoweth, D. M. Triptycene-based small molecules modulate (CAG).(CTG) repeat junctions. Chem. Sci. 2015, 6, 4752-4755.

27. Yang, Z.; Chen, Y.; Li, G.; Tian, Z.; Zhao, L.; Wu, X.; Ma, Q.; Liu, M.; Yang, P. Supramolecular recognition of three way junctions DNA by a cationic calix [3] carbazole. Chem. Eur. J. 2018, 24, 6087-6093.

28. Van Voorhis, W. C.; al., e. Open source drug discovery with the malaria box compound collection for neglected diseases and beyond. PLOS Pathog. 2016, 12, e1005763.

29. Wells, T. N.; Willis, P.; Burrows, J. N.; van Huijsduijnen, R. H. Open data in drug discovery and development: lessons from malaria. Nat. Rev. Drug Discovery 2016, 15, 661-662.

30. Mahuteau-Betzer, F. The french national compound library: advances and future prospects. Medecine sciences: $M / S$ 2015, 31, 417-422.

31. Kadrmas, J. L.; Ravin, A. J.; Leontis, N. B. Relative stabilities of DNA three-way, four-way and fiveway junctions (multi-helix junction loops): unpaired nucleotides can be stabilizing or destabilizing. Nucleic Acids Res. 1995, 23, 2212-2222.

32. Granzhan, A.; Monchaud, D.; Saettel, N.; Guédin, A.; Mergny, J.-L.; Teulade-Fichou, M.-P. “One ring to bind them all"-Part II: Identification of promising G-quadruplex ligands by screening of cyclophane-type macrocycles. J. Nucleic Acids 2010, 2010.

33. Freudenreich, J.; Barry, N. P.; Süss-Fink, G.; Therrien, B. Permanent encapsulation or host-guest behavior of aromatic molecules in hexanuclear arene ruthenium prisms. Eur. J. Inorg. Chem. 2010, $2010,2400-2405$

34. Gaschard, M.; Nehzat, F.; Cheminel, T.; Therrien, B. Arene ruthenium metalla-assemblies with anthracene moieties for PDT applications. Inorganics 2018, 6, 97. 
35. Stefan, L.; Bertrand, B.; Richard, P.; Le Gendre, P.; Denat, F.; Picquet, M.; Monchaud, D. Assessing the differential affinity of small molecules for noncanonical DNA structures. ChemBioChem 2012, $13,1905-1912$.

36. Laguerre, A.; Chang, Y.; Pirrotta, M.; Desbois, N.; Gros, C. P.; Lesniewska, E.; Monchaud, D. Surface-promoted aggregation of amphiphilic quadruplex ligands drives their selectivity for alternative DNA structures. Org. Biomol. Chem. 2015, 13, 7034-7039.

37. de Robillard, G.; Makni, O.; Cattey, H.; Andrieu, J.; Devillers, C. H. Towards sustainable synthesis of pyren-1-yl azoliums via electrochemical oxidative C-N coupling. Green. Chem. 2015, 17, 46694679.

38. Gabelica, V.; Rosu, F.; De Pauw, E. A simple method to determine electrospray response factors of noncovalent complexes. Anal. Chem. 2009, 81, 6708-6715.

39. Rosu, F.; Gabelica, V.; Houssier, C.; De Pauw, E. Determination of affinity, stoichiometry and sequence selectivity of minor groove binder complexes with double-stranded oligodeoxynucleotides by electrospray ionization mass spectrometry. Nucleic Acids Res. 2002, 30, e82.

40. Ragazzon, P. A.; Garbett, N. C.; Chaires, J. B. Competition dialysis: a method for the study of structural selective nucleic acid binding. Methods 2007, 42, 173-182.

41. Vichai, V.; Kirtikara, K. Sulforhodamine B colorimetric assay for cytotoxicity screening. Nat. Protoc. 2006, 1, 1112-1116.

42. Skehan, P.; Storeng; R.; Scudiero, D.; Monks, A.; McMahon, J.; Vistica, D.; Warren, J.T.; Bokesch, H.; Kenney, S.; Boyd, M. R. New colorimetric cytotoxicity assay for anticancer-drug screening, J. Natl. Cancer Inst. 1990, 82, 1107-1112.

43. Pommier, Y. Topoisomerase I inhibitors: camptothecins and beyond. Nat. Rev. Cancer 2006, 6, 789-802.

44. Hahn, W. C.; Counter, C. M.; Lundberg, A. S.; Beijersbergen, R. L.; Brooks, M. W.; Weinberg, R. A., Creation of human tumour cells with defined genetic elements. Nature 1999, 400, 464-468. 
45. Bonner, W. M.; Redon, C. E.; Dickey, J. S.; Nakamura, A. J.; Sedelnikova, O. A.; Solier, S.; Pommier, Y., $\mathrm{YH} 2 \mathrm{AX}$ and cancer. Nat. Rev. Cancer 2008, 8, 957-967

46. O'Connor, M. J. Targeting the DNA damage response in cancer. Mol. Cell 2015, 60, 547-560.

47. Kotera, N.; Poyer, F.; Granzhan, A.; Teulade-Fichou, M.-P. Efficient inhibition of human AP endonuclease 1 (APE1) via substrate masking by abasic site-binding macrocyclic ligands. Chem. Commun. 2015, 51, 15948-15951.

48. Caron, C.; Duong, X. N.; Guillot, R.; Bombard, S.; Granzhan, A. Interaction of functionalized naphthalenophanes with abasic sites in DNA: DNA cleavage, DNA cleavage inhibition, and formation of ligand-DNA adducts. Chem. Eur. J. 2019, 25, 1949-1962.

Graphical abstract for TOC:

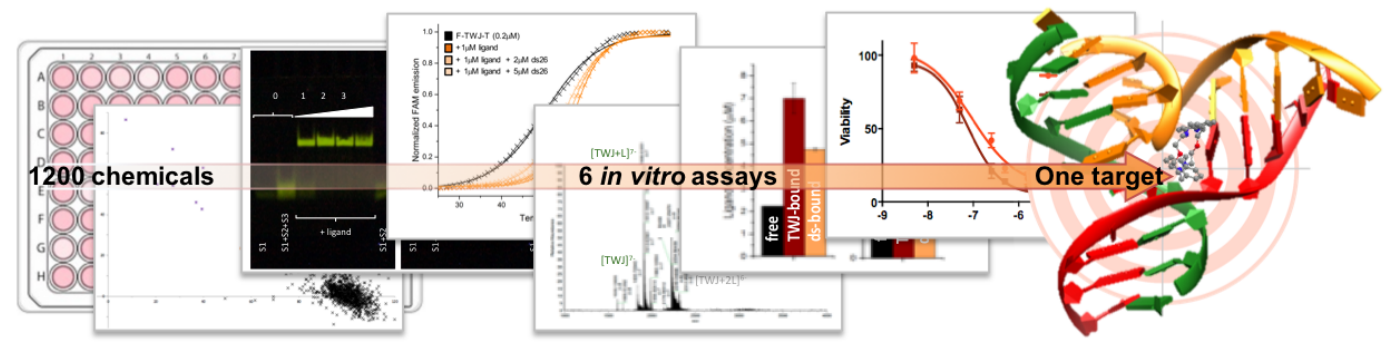

